\title{
MULTIFUNKCIONÁLIS JÁRMŰVEK ALKALMAZÁSA A KATASZTRÓFAVÉDELEMBEN
}

\section{THE APPLICATION OF MULTI FUNCTIONAL VEHICLES IN DISASTER MANAGEMENT}

\author{
VASS Gyula; ZSITNYÁNYI Attila \\ (ORCID: 0000-0002-1845-2027; ORCID: 0000-0003-3571-652X) \\ vass.gyula@uni-nke.hu; zsitnyanyi@gammatech.hu
}

\begin{abstract}
Absztrakt
A cikk megvizsgálja a katasztrófavédelmi feladatok során alkalmazott többcélú és többfunkciós járművek alkalmazásainak eseteit, célját és előnyeit. Összefoglalja a katasztrófavédelemben alkalmazott eszközrendszerek kialakulását, leírja a család és bázisjármű elvű jármüpark fejlesztések lépéseit és az azokban rejlő lehetőségeket, egyúttal rendszerezi a többcélú, többfunkciós és a cserefelépítményes jármüvekkel kapcsolatos magyar és angol nyelvü kifejezések használatát. Javaslatot tesz a Magyarországon létező cserefelépítményes és többfunkciós különleges képességek továbbfejlesztésére.
\end{abstract}

Kulcsszavak: multifunkciós jármüvek, többcélú jármüvek, katasztrófavédelem

\begin{abstract}
The article examines the cases, targets and advantages of the application of multi-purpose and multifunctional vehicles in disaster management operations. It summarizes the evolution of the tool systems applied in disaster management; describes the development phases of a vehicle fleet based on family - and base-vehicle-principles and their potentials, and also systemizes the application of the Hungarian and English terminology related to the multi-purpose, multifunctional and swapbody vehicles. The article proposes to the further improvement of the swap-body and multifunctional special capabilities currently existing in Hungary.
\end{abstract}

Keywords: multi-functional vehicles, multi-role vehicles, disaster management 


\section{BEVEZETÉS}

A katasztrófavédelemi tevékenységek végzéséhez szükséges eszközrendszerek fejlesztése napjainkban újra aktuális kérdéssé vált. A Széchenyi $2020^{1}$ [1] részeként a Környezeti és Energiahatékonyság Operatív Program (a továbbiakban: KEHOP) [2] programok keretében, részben európai úniós támogatás felhasználásával az utóbbi évtizedek legnagyobb léptékü müszaki fejlesztése történik a katasztrófavédelmi rendszerek fejlesztése területén. A program végrehajtása során a Belügyminisztérium Országos Katasztrófavédelmi Főigazgatóság (a továbbiakban BM OKF) képességeinek fejlesztése mellett a Magyar Honvédség Katasztrófavédelemmel összefüggő beavatkozási képességének fejlesztése is megvalósul.

A katasztrófavédelmi feladatok elhárítása szükségessé teszi a megfelelő személyi és müszaki technikai feltételek meglétét, amelyhez kapcsolódó eszközrendszer, eljárásrend és módszertan kutatása és fejlesztése önálló tudományos problémát és kutatási feladatot jelent.

A fejlesztés során történő beszerzésekhez kapcsolódó kommunikációkban több területen is megjelenik a többcélú vagy a többfunkciós kifejezés. Külföldi szóhasználatot is megvizsgálva azt feltételezem, hogy a kifejezések használata nem elég következetes, ezért meghatározom, hogy ezek a kifejezések mit is jelenthetnek a gyakorlatban.

A 2019 év végéig leszállítandó többcélú tűzoltógépjárművek kapcsán megvizsgáljuk, hogy a hasonló jármüvek rendszerbeállításának vannak-e előzményei itthon vagy külföldön?

A legtöbb országban létezik kifejezetten a katasztrófák/katasztrófahelyzetek kezeléséért felelős állami szervezet, van ahol saját minisztériummal is rendelkeznek. Hasonlóan más országok jogrendjében a katasztrófavédelemröl és a hozzá kapcsolódó egyes törvények módositásáról 2011. évi CXXVIII. törvény (a továbbiakban: Kat.) 1. §. (1) bekezdésére szerint, „A katasztrófavédelem nemzeti ügy. A védekezés egységes irányítása állami feladat.”[3], így mindenhol nagyon fontos szerepe van a katasztrófavédelemben közremüködő szervezeteknek, azok eszköz és személyi állománynak. Ezért nem csak a katasztrófavédelmi szervezetek által, hanem bármely katasztrófák elhárításában vagy annak következményeiben részt vevő szervezet által, a feladatok ellátása során alkalmazott különleges célú jármüveket is vizsgáljuk.

\section{MIT JELENT A MULTIFUNKCIONÁLIS JÁRMŰ KIFEJEZÉS?}

A hazai mértékadó tudományos szakirodalomban több hasonló kifejezést olvashatunk arra, amikor valaki azt szeretné hangsúlyozni, hogy az adott berendezés univerzális, vagy legalábbis több feladat ellátására képes. Ha a jármüveknél alkalmazott kifejezéseket vizsgáljuk, akkor leggyakrabban a multifunkcionális, többfunkciós és a többcélú kifejezésekkel találkozhatunk. Felmerülhet a gondolat, hogy a „critical infrastructure protection” fordításához hasonló esetről van szó, ahol a kritikus infrastruktúra védelem mellett a létfontosságú létesítmények és rendszerek kifejezés is elterjedt ahol az első években sokan azt gondolták két külön dologról van szó, nem pedig két különbözö változatú fordításról. Ha megvizsgáljuk, hogy milyen kifejezést alkalmaznak a nemzetközi szakirodalomban, sajnos akkor sem jutunk közelebb a megoldáshoz. A multi- function/functional (multifunkcionális, multifunkciós, többfunkciós), multi-role (többfeladatú vagy többcélú), multi-mission (többfeladatú vagy többcélú), multipurpose (többcélú) vagy swing-role (váltakozó feladatú) kifejezések köszönnek itt is vissza, különböző írásmódokkal (külön, kötőjellel és egybeírva) azonban ha megpróbáljuk a

\footnotetext{
${ }^{1}$ Az Európai Unió jelenlegi közös gazdasági stratégiája az Európa 2020 stratégia, ennek a magyar megfelelője a Széchenyi 2020 program. A program célja, hogy az Európai Unió a világ legversenyképesebb gazdasági és politikai közösségévé váljon a válság utáni új világrendben. Magyarország 2020-ig 12000 milliárd forint fejlesztési forrást használhat fel az Európai Unió és a hazai költségvetés támogatásával.
} 
kifejezéseket különböző képességeknek megfeleltetni első körben nem jutunk eredményre. Kutatásaim eredménye az lett, hogy a gyakorlatban szabadon alkalmazzák a kifejezéseket és itthon is mindenki a számára szimpatikus fordítást alkalmazza. Véleményem szerint a különleges célú jármüvekre vonatkozóan van értelme a kifejezéseket rendszerezni, hozzá definíciókat létrehozni és a jövőben eszerint alkalmazni őket.

„Multi-role vehicle” kifejezés a több (különböző) feladatra/szerepre szánt változatok kialakítására alkalmas bázisjármüvet (akár légi jármüvet) jelentette eredetileg, amely bázisán több, különböző célú jármüváltozat is kialakítható, ahol egy-egy változat egy konkrét feladat ellátására alkalmas. Az elsődleges motiváció a költségcsökkentés volt az azonos alapeszköz kialakítás miatt. Ezeknél a jármüveknél más megjelenik a családelv, vannak azonos elemek, azonban a különböző feladatok ellátása érdekében jelentős eltérések lehetnek a kivitelekben. Ezek az eszközök azonban a speciális kialakításukból adódóan nem alkalmazhatók egy küldetésen belül különbözö feladatokra.

A „multi-purpose vehicle” (többcélú jármű) kifejezés gyakorlatilag a „multi-role vehicle” szinonimája, eredetileg a személygépkocsiknál az egyterüt jelenti, az egész világon közismert HMMWV (High Mobility Multipurpose Wheeled Vehicle - magyarul nagy mozgékonyságú többcélú kerekes jármü) tette leginkább elterjedté ezt a kifejezést. Napjainkban már használják ezt a kifejezést a gyorsan átalakítható járműveknél is, pedig ez a képesség alapvetően a „swingrole vehicle" kategóriára igaz.

A „swing-role vehicle” olyan váltakozó feladatú jármüvet jelent ahol egy-egy müveleten belül is változtatható a speciális felépítmény, kiegészítő készlet vagy képes akár egy időben több speciális feladat végrehajtáshoz szükséges kiegészítőt is hordozni. Ez a kifejezés mostanában terjed a katonai terminológiában elsősorban légi jármüveknél, azonban a váltakozó feladatú jármüvek egyben „multi functional” (több mint egy funkcióval rendelkező) jármüvek is, így tekinthetjük őket egymás szinonimájának. [4]

A rengeteg kifejezés megjelenésének marketing okai is lehetnek, a fejlesztő cégek szeretnek hangzatos elnevezéseket adni a vélt vagy valós új képességekkel rendelkező berendezéseiknek. Ilyen próbálkozás volt a nem túl elterjedt „multi-mission” elnevezés amit többcélú és többfeladatú szövegkörnyezetben használnak de a termékek amelyeknél alkalmazták inkább a többfunkciós kategóriába esnek.

A kifejezések használata alapján úgy tünik, hogy azok csereszabatosak de ha megvizsgáljuk a megjelenések környezetét akkor kiderül, hogy a „,nem minden rovar bogár de minden bogár rovar" esete forog fent.

\section{A többcélú és a többfunkciós járművek definíciója}

Meghagyva a hasonló kifejezések használatának szabadságát, a különleges célú (katonai, tüzvédelmi, katasztrófavédelemi, polgári védelmi, rendőrségi) jármüveknél történő alkalmazásuk céljából célszerünek látom a csoportosításukat és a következő definíciók szerinti alkalmazásukat:

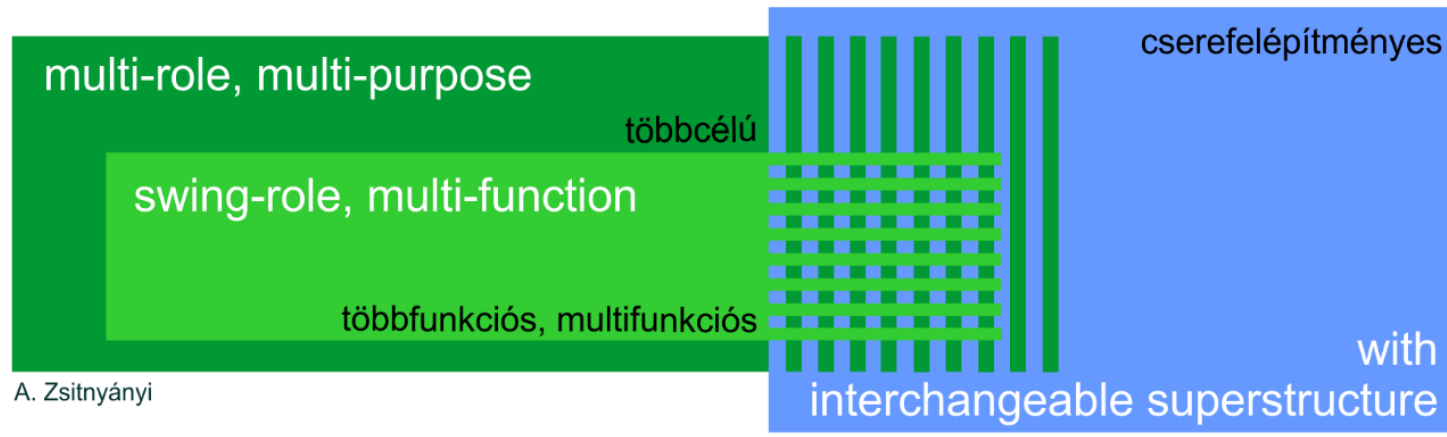

1. ábra Különleges célú járművek csoportosítása képességeik szerint (a szerző szerkesztése) 
A multi-role / multi-purpose vehicle magyar megfelelői a többcélú / többfeladatú jármü kifejezések. Többcélú jármü: különböző speciális feladatok végrehajtása érdekében a bevetések közötti átalakításra vagy speciális kivitelü változatok kiépítésére alkalmas jármüvet jelenti.

A multi-function / swing-role / multi-mission vehicle magyar megfelelői a többfunkciós / multifunkciós jármü kifejezések. Többfunkciós jármü: az egy bevetés alatt, gyors váltásokkal, több speciális feladat végrehajtásának képességével rendelkező jármüvet jelenti.

Mind a kettő csoportba tartozó jármüveken alkalmazhatunk cserélhető felépítményeket/modulokat. Az alapjármüre felhelyezhető modulok közvetlenül a jármüböl, azok közremüködésével müködtethetőek.

Nem része ezeknek a kategóriáknak az a speciális eset, amikor a cserélhető felépítményeket hordozó jármü alapvetően egy általános szállító jármü és a modulok bár müködtethetőek a szállító jármüvön, de a jármütől leemelve, attól teljesen függetlenül is alkalmazhatóak. Azt gondolom, hogy ezekre a jármüvekre a megfelelő kifejezés egyszerüen csak a cserefelépítményes hordozó vagy szállító jármü.

\section{KATASZTRÓFAVÉDELEMBEN ALKALMAZOTT JÁRMŰVEK}

\section{Katasztrófavédelemben alkalmazott eszközrendszerek kialakulása}

A katasztrófavédelmi, rend- és honvédelmi szervezeteknél alkalmazott eljárások a második világháborút követően azonos vagy nagyon hasonló eszközrendszerekre alapultak (azonos egyéni védőeszközök, műszerek, járművek). Kezdetben a rendelkezésre álló készletek miatt alakult így, azonban a későbbiekben is segítette a költséghatékony elöállítást, beszerzést, karbantartás és egyben a kiképzéseket is. Napjainkban a specializálódás és az ezzel párhuzamos költségvetési megszorítások miatt azonban egyre jobban terjed a különböző szervezeteknél a különböző technikai eszközök alkalmazása.

A katasztrófavédelmi szervezetek által alkalmazott eszközrendszerek a speciális kialakításuk miatt is nagyon költséges berendezések, a kis darabszámok és a ritka alkalmazás miatt pedig nehézséget okoz a megfelelően képzett felhasználói állomány kiképzése és a gyakorlatuk megtartása. Amíg az eszközrendszerek nagyjából azonosak voltak a hadseregek eszközeivel és a legtöbb országban még létezett a sorkatonaság intézménye, legalább az alapvető polgári védelemben is alkalmazott eszközök használata szélesebb körben is ismert volt (például: $\mathrm{ABV}^{2}$ védelmi felszerelések, különleges jármüvek használata és sátrak építése).

Katasztrófavédelmi feladatokra alkalmas különleges célú jármüvekkel a legtöbb országban még a hadseregek rendelkeznek, így van ez Magyarországon is.

A Kat. 2. § (1) bekezdése szerint „A védekezést és a következmények felszámolását az erre a célra létrehozott szervek és a különbözö védekezési rendszerek müködésének összehangolásával, az állampolgárok, valamint a polgári védelmi szervezetek, a gazdálkodó szervezetek, a Magyar Honvédség, a rendvédelmi szervek, a Nemzeti Adó- és Vámhivatal, az állami meteorológiai szolgálat, az állami mentöszolgálat, a vízügyi igazgatási szervek, az egészségügyi államigazgatási szerv, az önkéntesen részt vevö civil szervezetek és az erre a célra létrehozott köztestületek, továbbá nem természeti katasztrófa esetén annak okozója és elöidézője, az állami szervek és az önkormányzatok (a továbbiakban együtt: katasztrófavédelemben részt vevők) bevonásával, illetve közremüködésével kell biztositani." [3

${ }^{2}$ Atom-Biológiai-Vegyi 
A Magyar Honvédség (MH) egyik kiemelkedő feladata, hogy közremüködjön a katasztrófák elleni védekezésben, speciális eszközeivel, felkészült és elhivatott katonáival, legyen szó akár a katasztrófavédelem valamely szereplőjének megerősítéséről, akár annak önálló feladat végrehajtásról. Az egyre nagyobb számú, a hivatásos katasztrófavédelmi szervek beavatkozó képességét meghaladó, konkrét honvédségi közremüködést igénylő események indokolják a Magyar Honvédség Katasztrófavédelemmel összefüggő beavatkozási képességének fejlesztését KEHOP-1.6 forrásokból is, mely során jelenlegi, katasztrófavédelmi közremüködések során használt Honvédelmi Katasztrófavédelmi Rendszer (HKR) képességeit fenntartja és bővíti azok kapacitását. A projektben megvalósuló fejlesztések a vízi és földi szállítási, földmunka, daruzási, müszaki mentési, áramellátási és tábori elhelyezési kapacitások megújítását és bővítését is szolgálják. [5],[6],[7] A Magyar Honvédség többek között a Belügyminisztérium, Országos Katasztrófavédelmi Főigazgatóságánál is rendszeresített berendezéseket vásárolt vagy újított fel.
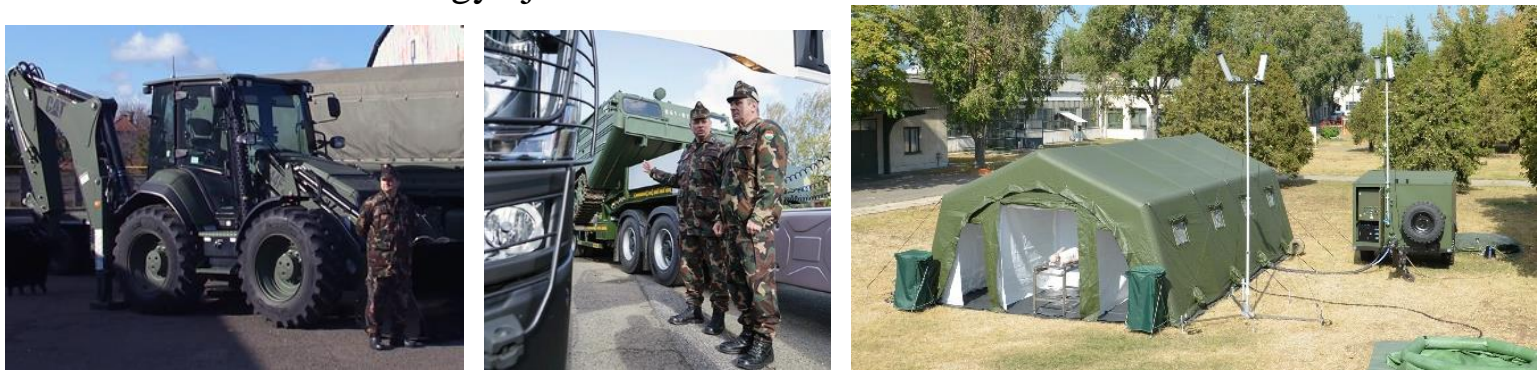

2. ábra HM által KEHOP program keretében beszerzett eszközök (Forrás: [5],[6],[11])

\section{Katasztrófavédelmi feladatok során alkalmazott többcélú és többfunkciós jármüvek}

A speciális, viszonylag kis számban előforduló feladatokhoz elkülönített felszerelések készenlétben tartása - az egyre sokasodó, szerteágazó feladatkörök miatt - elkerülhetetlenné vált. A hagyományos (rögzített felépítményes) jármükialakítás, sajátosságaiból eredően, minden speciális felépítményhez (felszereléshez) külön gépjármü üzemben tartását igényli. A különleges célú gépjármüvek olyan technikai eszközökkel vannak ellátva, melyek használatához a kezelő állománynak megfelelő szakértelemmel kell rendelkeznie. Sok esetben problémát jelent, hogy egy szer meghibásodása esetén, a helyette biztosított másik, eltérő típusú gépjármühöz nincs megfelelö képesítéssel rendelkezö helyi kezelöszemélyzet. Ugyanakkor a gépjármüvek sokfélesége igényli az egyéni vezetés- technikai ismeretek elsajátítását is. Egy egységes jármüpark alkalmazásával a személyi felelősségre visszavezethető vezetés technikai hibák miatt kialakuló balesetek száma is jelentősen csökkenthető, elkerülhető. A gépjármüpark homogenizálása gazdaságossági szempontból lehetővé teszi az egyszeri nagy értékü alkatrész beszerzést és azok raktározását. Az azonos típusú, üzemeltetési és üzemben tartási igényü gépjármüvek előnyt jelentenek a gépjármüvek országos szintü logisztikájának tekintetében is. Egy készenlétben tartott gépjármü, kiesése esetén, könnyen pótolható egy azonos kapacitású és azonos paraméterekkel rendelkező gépjármüvel, így a kezelőszemélyzet késedelem nélkül tovább folytathatja alapfeladatát.

Amíg a gépjármüfecskendőknél néhány kategória alkalmazásával, idővel el lehet érni, hogy viszonylag homogén eszközrendszer álljon rendelkezésre, addig az iparbiztonsági vagy polgári védelmi célú különleges jármüveknél a csere felépítményes szállító járművek mellett a többfunkciós jármü és felépítményrendszerek jelenthetik a megoldást.

Katasztrófavédelmi szervezeteknél, Európában elsősorban a horgos emelös a DIN 14505 szabványnak megfelelő csere felépítményes járművek terjedtek el. Az emelőhorgos rendszer biztosítja a speciális konténerek szállítását, gyors cseréjét, azonban a nehéz terepi használatot nem teszi lehetővé a magas súlypont miatt. Nehezen megközelíthető jó minőségü kiépített 
utakkal nem rendelkező kistelepülések, tanyák megközelítése során, a terepjárási képességekkel nem rendelkező jármüvek gyakorlatilag mozgásképtelenné válnak.

A különleges feladatokra szánt (például: erdő és vegetációs tüzek oltására alkalmas) járműveiket (a vezető európai gyártók közül többek között a CAMIVA, a Rosenbauer, THT és a Magirus cég) 4x4 és 6x6 Renault, Iveco, MAN, Mercedes és Unimog alvázakra építik, amelyek azonban fix felépítményekkel rendelkeznek. Az Oshkosh katonai alvázra kifejlesztett taktikai tüzoltó jármü egy nehézterepi környezetre kialakított eszköz, 4 fö szállítására alkalmas, azonban csak alap oltási képességekkel és mindössze egy 4000 literes víztartállyal rendelkezik.

A polgári gyártóknál található nehézterepi, cserefelépítményes eszközök fizikai hatásokkal szembeni védettsége megegyezik a közúti változatokéval, ezért több országban is megjelentek a páncélozott tüzoltó és müszaki mentő jármüvek. A növelt védettség lehetőséget biztosít más, már a katasztrófavédelem rendszerében lévő eszközzel nem megközelíthető veszélyes müveleti területen való beavatkozásra is. A jármü meg tudja közelíteni azon tüz gócpontokat, ahol fennáll a robbanásveszély, illetve feltételezhetö különböző mérges gázok, gőzök, egyéb légnemü égéstermékek jelenléte, valamint hogy biztonságosan bevethető előzőleg fel nem térképezett területeken való feladatok végrehajtására, a személyi állomány védettségének biztosítása mellett (pl. robbanószerkezetek, felrobbanó gáztartályok repeszei, nagyobb ledőlő faágak, stb. által okozott sérülések). Ezek a járművek leginkább a katonai jármüveket gyártó cégek kínálatában jelennek meg, Csehországban a Tüzoltóság 3 db 8x8 kerékképletü Tátra (TATRA T815-7 FORCE) alvázra épített páncélozott gépjármüfecskendőt és 3 db 4x4 -es 20001 oltóanyag kijuttatására is képes páncélozott parancsnoki és felderítő jármüvet vásárolt $3 \mathrm{db}$ 10x10 kerékképletü nagykapacitású (240001) nehézterepi vízszállító és 3 db 8x8-as müszaki mentő jármü mellett. A müszaki mentő feladata többek között a többi nehéz jármü bevetésekor azok műszaki támogatása, az utak megtisztítása, egyéb járművek müszaki mentése és a sérült jármüvek félreállítása.[8] Az Oshkosh cég hasonló páncélozott mentö-vontató jármüve is egy 12 méter hosszú 8x8-as alapjármüvön lett kifejlesztve, saját tömege 48 tonna!
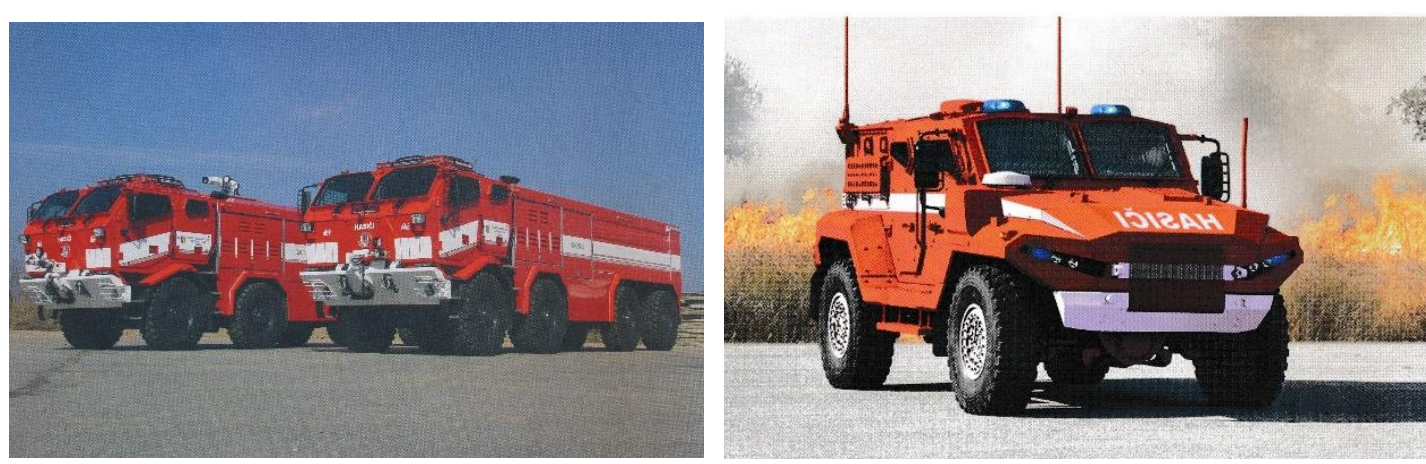

3. ábra Cseh tüzoltóság különleges jármüvei (Forrás: [8])

A fenti katonai müszaki mentő eszközök csak katonai alkalmazásokra kifejlesztett felépítményekkel rendelkeznek, önállóan nem vethetőek be katasztrófavédelmi feladatok során a müszaki mentéssel egy időben előforduló kisebb tüzek oltására sem. Kimondottan növelt fizikai védelemmel ellátott katasztrófavédelmi célra használható cserélhető felépítményes jármüvet külföldön még nem gyárt egyetlen vállalat sem.

\section{Többfunkciós járművek szerepe a katasztrófa védelemben}

Nehézséget jelent, hogy a tüzoltóságok nem rendelkeznek megfelelő számban olyan speciális jármüvekkel, amelyek használatára nagyon ritkán kerül sor, így amellett, hogy ezen berendezések területi elhelyezését nagyon körültekintően kell kiválasztani, keresni kell azokat 
a megoldásokat, amikor egy-egy speciális jármü akár több funkciót is képes ellátni, növelve így a bevethetöségüket, "megtérülésüket".

A különleges célú járművek fenntartása költséges, ezért optimális megoldás a többfunkciós, és cserélhető felépítményes megoldásunk alkalmazása. Itt lehetőség van arra, hogy az adott múvelet sikeres végrehajtásához szükséges berendezések, felszerelések az erre kialakított felépítményekbe kerüljenek elhelyezésre, melyek rövid idő alatt ráhelyezhetőek egy többfunkciós alapjármüre. A többfunkciós, cserélhető felépítményes gépjármüvek nem igényelnek külön logisztikai bázist, hiszen maga a cserefelépítmény szabad téren is elhelyezhető, az alapjármü pedig eközben igény szerint üzemeltethető egyéb feladatokra.

\section{KATASZTRÓFAVÉDELMI FELADATOKRA ALKALMAZOTT TÖBBCÉLÚ ÉS TÖBBFUNKCIÓS JÁRMÜVEK MAGYARORSZÁGON}

Érdemes megvizsgálni egy konkrét példán, hogy milyen előzmények után jutottunk el a napjainkban divatos családelvü, többcélú és többfunkciós eszközpark kialakításokhoz. Tekintettel arra, hogy a katasztrófavédelemben nem csak a hivatásos katasztrófavédelmi vesznek részt ezért a folyamatot a Magyar Honvédség (korábban Magyar Néphadsereg) mühely gépkocsi parkjának alakulásán mutatom be. A 60-as évekre a hadseregeknél is alkalmazott technikai eszközök összetettsége jelentősen megnövekedett, a megváltozott helyzet egyre bonyolultabb feladatokat támasztott a technikai biztosítás területén is. Az 50 es években kifejlesztett mühely gépkocsik első generációját közúti tehergépkocsik alvázain (Csepel B-350, MÁVAG B-5, SKODA-706) elhelyezett, fa vagy fém és fa szerkezetü, egyedi kialakítású felépítmények jellemezték. Az 1960-as évek végétől alkalmazott második generáció már azonos típusú bázisalvázakon (Csepel D-344 és 346), egységes zárt felépítményekkel (EZF) kerültek kialakításra. Ahogy az igények sokfélesége megnövekedett és az ezek kielégítéséhez szükséges járművekkel szemben támasztott követelmények egyre nőttek, az 1980-as évek elején kialakított 3. generációs mühely gépkocsik már nagyobb teherbírású (5t), 6x6 kerékképletü, csörlővel is ellátott katonai terepjáró gépkocsi alvázon (DAC-665 GTG, ZIL131, URAL-375) kerültek kialakításra, amelyeket alkalmassá tettek 10 lábas ISO konténeres rögzítési helyekkel rendelkező felépítmények hordozására. Egy új egységes felépítmény (KF2) is kialakításra került.[7] A katasztrófavédelemben is alkalmazott jármüvekhez talán legközelebb álló müszaki technikai szolgálat több speciális eszköze TÁTRA alvázon volt (pl. darus gépkocsi, kotró stb.) Ezek a példák azt mutatják, hogy egyre növekedett az igény a többcélú bázisjárművek rendszeresítésére és még a különböző speciális felépítmény kialakításoknál is törekedtek az egységes felépítmény használatára. A 2003 áprilisában kötött hosszú távú gépjármü beszerzési keretszerződés, ezt az irányt folytatta, amely alapján a Rába Jármü kft különleges felépítmények hordozására is alkalmas, köztük a speciálisan az $\mathrm{MH}$ számára kifejlesztett „H-14,18,25” típusjelű RÁBA változatokat kezdett el szállítani.

A helyi tüzoltóságok önkormányzati kézben müködtek 1995-től, 2012. január 1-ig. Ez idő alatt a különböző forrásokkal rendelkező tüzoltóságok lehetőségei miatt, még az azonos feladatokra alkalmazott szakfelszereléseknél és járműveknél is heterogén eszközrendszer alakult ki akár a típusokat vagy az állapotukat vizsgálva. 2012. január 1-jén a katasztrófavédelemnél teljes egészében megtörtént az integráció. Ennek eredményeként a hivatásos önkormányzati tüzoltóságok (HÖT-ök) megszüntek létezni. Helyettük hivatásos tüzoltó-parancsnokságok jöttek létre (HTP-k), melyek a katasztrófavédelem helyi szerveként müködnek tovább; valamint létrejöttek az Önkormányzati Tủzoltóságok (ÖTP) is, amelyek nem hivatásos, hanem civil munkavállalókból állnak, és nem képezik részét a katasztrófavédelemnek. [10] Az átszervezést követően, feladatként fogalmazódott meg egy egységesebb jármüparki kialakítása, a vízszállító járművek gyártása során szerzett tapasztalatokat is felhasználva, hazai gyártású gépjármüfecskendő kialakítása. Logikusnak tünt, 
hogy az MH által rendszeresített MAN alapokra épülő RÁBA sorozat egyik tagja legyen az új gépjárműfecskendők bázisjármüve, amelyet azonban az első prototípus (M16) elkészítését követően lecseréltek egy új, Renault alapokon nyugvó RÁBA jármüre (R16). A prototípus elkészítését követő mennyiségi ellátásnak új lendületet adott a KEHOP-1.6.0-15-2015-00001 program. Amely területeken már nem lehet teljesen azonos eszközrendszereket alkalmazni, ott törekedni kell arra, hogy legalább a szervezeteken belül azonos eszközrendszerek legyenek. 2014 és 2020 között összesen száznyolc, teljes málhával felszerelt gépjármüfecskendő kerül átadásra.

Magyarországon a mentő-tűzvédelmi feladatok ellátására jelenleg 30 darab erdőtüzek oltására alkalmas gépjármü és 92 vízszállító áll a hivatásos tüzoltó állomány rendelkezésére. A hivatásos tüzoltó-parancsnokságokon és katasztrófavédelmi örsökön 1,2 vagy $3 \mathrm{db}$ gépjármüfecskendő és a müködési terület veszélyeztetettségének megfelelően egyéb különleges szer vagy szerek (magasból mentők, müszaki mentö-, erdőtüzes-, különleges teherés konténerszállító gépjármüvek, daruk, stb.), összesen 699 jármü áll készenlétben. Ezek között megtalálhatóak többcélú és többfunkciós jármüvek is.

Országosan 20 darab DIN 14505 szabványnak megfelelő, horgos emelős csere felépítményes hordozójármű szállítási kapacitása a meglévő szállítóplatós, vegyi, müszaki mentő stb. konténerek mellett további speciális (töltésvédelmi, csónakszállító, szivattyús, logisztikai, bevetés irányítási, szociális, pihenő és egészségügyi konténer, áramellátást biztosító, áramfejlesztő, habbal és porral oltó, mentesítő, légző bázis, erdőtűzvédelmi, étkeztető stb.) konténerek rendszerbe állítását teszi lehetővé.
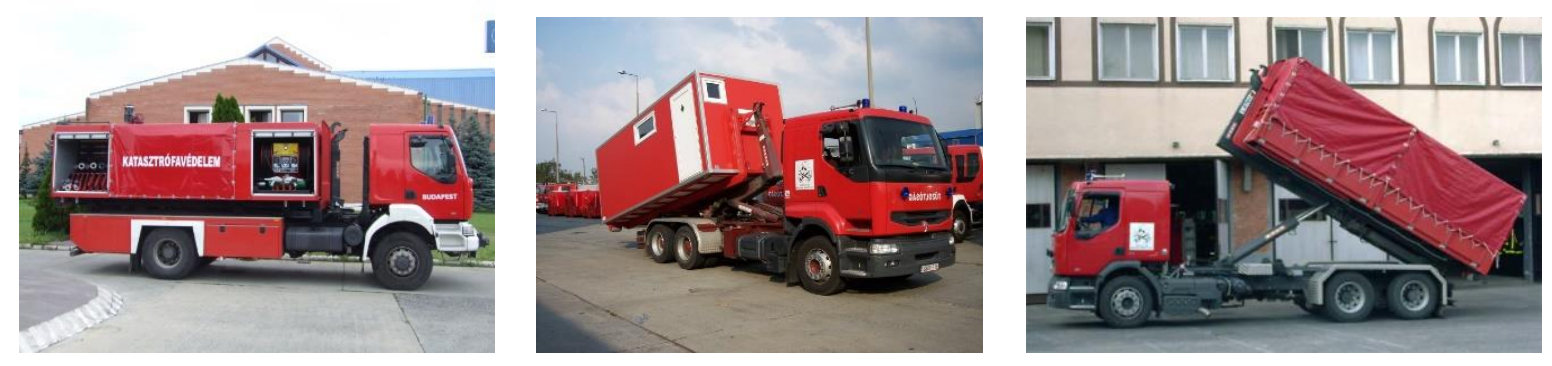

4. ábra Konténerszállító gépjármű hab-por oltó, légzőbázis, univerzális platós konténerrel (Forrás: [11])

A többcélú jármüvek mellett megjelentek a többfunkciós kialakítások is. Mentő tüzvédelemben alkalmazható megoldásként 2015 augusztus végén mutatták be a BM Heros Zrt. által fejlesztett egy Mahindra bázisjármüvön bemutatott, cserefelépítményes gyorsbeavatkozó szer prototípusát. Mozgékonyságának és terepjáró képességének köszönhetően a hagyományos gépjármüfecskendőnél gyorsabban képes a riasztás helyszínére kiérni, mostoha terepviszonyok között is. Az alap beavatkozáshoz szükséges felszerelésekkel felmálházott felépítmény cseréjével árvíz, belvíz vagy egyéb eseteknél gyorsan hadra fogható új eszközhöz juthatunk. [12],[13] 


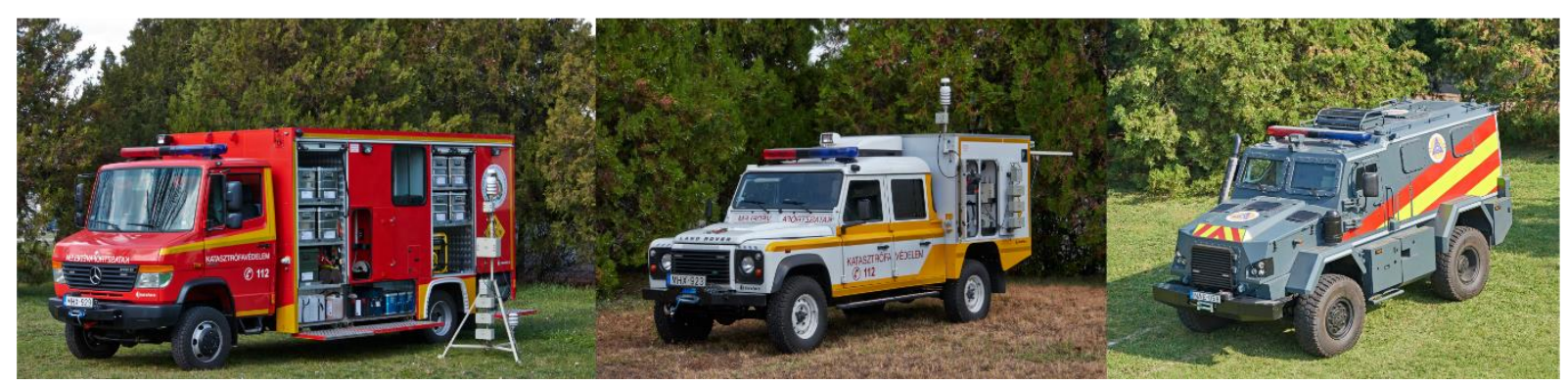

5. ábra KML, KML-ADR, és sugárvédett KOMONDOR járművek (Forrás: [11])

Az iparbiztonsági területen is új, többfunkciós jármüvek kerültek rendszeresítésre. A katasztrófavédelem által müködtetett Veszélyhelyzeti Felderítő Csoportokat és a Veszélyhelyzeti Felderítő Szolgálatot 2012. január elsejétől korszerübb formában a Katasztrófavédelmi Mobil Laborok (KML) váltották fel. A Katasztrófavédelmi Mobil Labor (KML) és annak csökkentett képességű változata (KML-ADR) egy időben képes veszélyhelyzet értékelésre, sugárfelderítésre, vegyifelderítésre, mentesítésre, emellett közúti ellenőrzések végrehajtása során mobil irodaként is funkcionálnak. [14] Az MVM Paksi Atomerőmü Zrt. balesetelhárítása számára beszerzett magyar fejlesztésü KOMONDOR jármü egyszerre képes sugárfelderítésre és sugárvédett környezetben a beavatkozás helyszínére szállítani a beavatkozókat.

\section{A jövő}

A korábban említett KEHOP-1.6.0-15-2016-00020 azonosítószámú projekt célja, hogy új vízszállító és erdőtüzoltó, erdőtüzes gyorsbeavatkozó, valamint többcélú tűzoltógépjármüvek vásárlásával a katasztrófavédelem erői még rövidebb idő alatt, nagyobb kapacitással, modernebb felszerelésekkel vonulhassanak a kárhelyszínre, hatékonyabban tudják felszámolni a károkat, mindezt úgy, hogy az alkalmazott eszközök, valamint beavatkozási eljárások által okozott negatív környezeti hatások a lehető legalacsonyabb intenzitással jelentkezzenek. A projekt keretén belül várhatóan ötvenhét különböző jármủ és négy cserefelépítmény rendszerbe állítása történik meg. Ennek keretében került sor 3 db, 6x6-os kerékképletủ nehéz terepi többcélú jármü beszerzésére, vízszállító/erdőtüzes és müszaki mentő cserefelépítménnyel.

A megvalósítás alatt álló többcélú gépjármü katasztrófavédelmi rendszerben meglévő konténeres telepíthető képességektől koncepciójában lényegesen eltérő, mobil komplex beavatkozó képesség egy speciális, védettségében növelt eszköze lesz. Maga az elgondolás lényege, hogy olyan képesség teremtödjön meg ahol az adott többcélú eszköz nem csak hordozó, de egyben beavatkozó eszköz is, alkalmazási képessége pedig az aktuális, modulárisan változtatható kialakításától függ. A jármü alkalmas a vízszegény területeken a gépjármüfecskendők vízutánpótlásának biztosítására, használható egy teljes raj szállítására, de önálló beavatkozó jármüként is bevethető az általános tüzoltási és az erdőtüzes oltási feladatok ellátása érdekében. Olyan speciális oltástechnikai elemeket (pl. orrmonitorok, önoltó képesség, UHPS berendezés) tartalmaz, ami alkalmassá teszi akár kiterjedt, intenzív vegetációtüzek elleni alkalmazásra is.

A duplafülkés többcélú gépjármü három különálló egységből épül fel, a duplafülkés alapjármüből, a vízszállító-erdőtüzes cserefelépítményből, valamint a müszaki-mentő cserefelépítményből. A bázisjármü a Komondor jármücsalád speciálisan erre a célra tervezett RDO-4332 típusjelzésủ félplatós 6x6 kerékképletủ változata. 


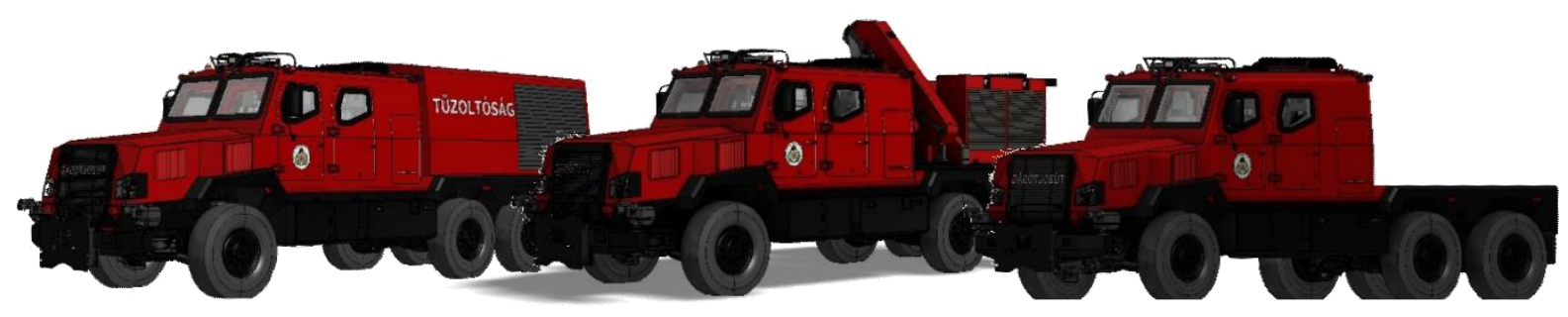

6. ábra RDO-4332 KOMONDOR bázisán kialakításra kerülő nehéz terepi többcélú gépjármü (Forrás: [11])

A nehéz terepi többcélú gépjármü alkalmas közúton, közepes és nehéz terepviszonyok között, nagy tömegü oltóanyag és/vagy felszerelések szállítására. A különböző cserélhető felépítmények alkalmazásával a jármü felhasználható nehéz terepi (erdei) vízszállítás, erdei tüzoltás, árvízvédelmi felszerelések szállítása valamint egyéb logisztikai és oltási feladatok ellátására. A Műszaki mentő cserefelépítmény a jármü csatlakozó pontjaira illeszkedő rögzítő vázkeretre került ráépítésre, ami megfelelően kialakított emelési pontok segítségével biztosítja az egész egység daruval történő le-, és felemelését a cserefelépítmények váltása során. A Vízszállító-erdőtüzes cserefelépítmény magába foglalja a müanyag víztartályt, a nagynyomású üzemre is alkalmas tüzoltó szivattyút és annak hajtás elemeit, a habrendszert, a tüzoltástechnikai vezérlés kezelő felületét. Lehetőséget biztosít közúti ellátási pontról nehezen megközelíthető, vagy közúti jármüvekkel el sem érhető müveleti területekre akár 70001 víz egyidejü kijuttatására. A kialakított rendszer biztosítja a tartály gyors töltését és leürítését. A képesség kiegészítésre kerül egy olyan szivattyú, vegyszeradagoló, fúvóka elemeket tartalmazó rendszerrel, ami képessé teszi nagy területek fertőtlenítésére is.

\section{KÖVETKEZTETÉSEK}

Fontos eredménynek tartjuk, hogy tisztázásra került a többcélú, többfunkciós és cserefelépítményes különleges járművek definíciója. Az egységes fogalomhasználat segíti nem csak a felhasználók vagy igénytámasztók eligazodását, de a rendszerek fejlesztésében gondolkodók számára is világosabbá teszi, mely kategóriának mi lehet a célja.

A $3 \mathrm{db}$ hazai fejlesztésü nehéz terepi többcélú gépjármü a katasztrófavédelem és a tűzoltóságok széles körben bevethető beavatkozó eszközévé válhat. További cserélhető felépítmények alkalmazásával használható nehéz terepi vízszállításra, fertőtlenítésre, kiemelt közúti baleseteknél müszaki beavatkozáshoz, egyéb logisztikai és oltási feladatok ellátására, személyszállításra, sérültek biztonságos ellátó helyre történő eljuttatására, vezetési pontként történő müködésre.

A hazai védelmiipar szerelői számára is lehetőség, hogy egy hazai jármühöz fejleszthetnek kiegészítőket, ezért véleményem szerint érdemes továbbmenni az úton és a következő felépítményeket, kiegészítőket kifejleszteni, rendszeresíteni:

Egy univerzális zárt felépítmény, alapját képezheti mindazon képességnek, ahol előtérbe kerül a hat fös bevetési állományon felüli élő erő megóvása, munka-élet körülményeinek megteremtése. A sebesült-, személyszállító felépítmény kiegészítéssel alkalmas lehet 10 személy egyidejü szállítására vagy 2 fekvőbeteg és 4 ülő személy ellátó helyre történő biztonságos eljuttatására, hideg körülmények között melegedöként való müködésre. A hómaró adapter alkalmazásával egyidejűleg ez a kialakítás ideális képességet biztosít téli időszakokban a hófúvásoktól elzárt helyeken rekedt személyek kimentésére, utánpótlás, ellátmány szállítására. 
A több célú jármüre rögzített bevetés irányítási felépítmény a beavatkozó szervezetek irányítási eszköze lehet a müveleti területeken kimondottan nehezen megközelíthetö terepviszonyok között is, közel a beavatkozás helyéhez, ahol a védettségen túlmenően fontos szempont a gyors rugalmas helyváltoztatás szükségessége is.

A többcélú járműhöz kifejleszthető terepi használatra alkalmas több funkcióval rendelkező felépítmény szállító nehéz pótkocsi. Egy részről mobil tárolási lehetőséget biztosíthat az épp nem használt felépítmények számára, másrészt lehetővé teheti az alapjármüvön rögzített felépítményen meglévő képesség müveleti területen történő kiterjesztését egy további felépítmény funkciójának megjelenítése révén. A pótkocsin szállított egyéb felépítmény képességével kiegészítve, mint rendszer lehet képes biztosítani a vezetési törzs folyamatos munkavégzéséhez, szükséges feltételeket, a bevetésirányító személyzet folyamatos munkavégzését, az ahhoz szükséges felszerelések, berendezések tárolását, szállítását, megfelelő munkakörülményeket a személyzet számára a bevetés teljes időtartama alatt.

A katasztrófa sújtotta területeken müködtetett, katasztrófavédelmi feladatot végrehajtó állomány a fejlesztések eredményeképpen kárhelyszínen fennálló nehézségek közepette alkalmazható/müködő eszközök/eszközrendszerek birtokában lehet. Minimális átalakítással, esetleges speciális kiegészítésekkel a jármü alap védettségéből adódóan jól alkalmazható lenne a Magyar Honvédség vagy a BM további szervezetei kötelékében is, nem csak katasztrófavédelmi feladatokra. Érdemes megvizsgálni, hogy a BM OKF-nél található gépjármüfecskendőknél alkalmazott bázisjármüvek, az új 6x6-os nehézterepi jármü vagy az MH által alkalmazott RÁBA járművek bázisán milyen egyéb többfunkciós változat kialakításának lehet létjogosultsága. Az új modulok, nem csak a hazai szakmai képességeket erősítenék, hanem kiváló exportlehetőséget is jelentenének, amely segíthet a további tapasztalatok megszerzése mellett a hazai háttéripar gazdaságos müködéséhez is hozzájárulni, így is növelve a gazdaságbiztonságot. További kutatásaink során ezekkel a kérdésekkel is kívánunk foglalkozni.

\section{FELHASZNÁLT IRODALOM}

[1] Széchenyi 2020 program, https://szechenyi2020.hu (letöltve: 2019.03.31.)

[2] Környezeti és Energiahatékonyság Operativ Program (KEHOP), https://www.kehop.hu/kehop/, (letöltve: 2019.03.31)

[3] 2011. évi CXXVIII. törvény a katasztrófavédelemröl és a hozzá kapcsolódó egyes törvények módositásáról, $\quad$ https://net.jogtar.hu/jogszabaly?docid=A1100128.TV, 2019.03.31.)

[4] UK MINISTRY OF DEFENCE, Defence Concepts and Doctrine Centre: UK Air and Space Doctrine (JDP 0-30)

https://assets.publishing.service.gov.uk/government/uploads/system/uploads/attachment_d ata/file/668710/doctrine_uk_air_space_power_jdp_0_30.pdf (letöltve: 2019.03.15.)

[5] Egymilliárd forintot meghaladó Európai Uniós támogatásból valósul meg a Magyar Honvédség katasztrófavédelmi eszközparkjának újabb fejlesztése https://honvedelem.hu/cikk/111826_egymilliard_forintot_meghalado_europai_unios_tamo gatasbol_valosul_meg_a_magyar_honvedseg_kata (letöltve: 2019.02.14.)

[6] Honvédelem.hu: Kapacitásbővités, Újj eszközök a károk enyhitésére https://honvedelem.hu/cikk/109728_kapacitasbovites (letöltve: 2019.02.14.) 
[7] A Magyar Honvédség Katasztrófavédelemmel összefüggö beavatkozási képességének fejlesztése KEHOP-1.6.0-15-2016-00003 projekt, https://www.ket.hm.gov.hu/palyazatok/Letlthet\%20anyagok/KEHOP\%201.6.0-152016/sajt\%C3\%B3anyag.v\%C3\%A9gleges_0220.pdf (letöltve: 2019.03.15.)

[8] Fire rescue service pp. 12-15. In: CHECH DEFENCE INDUSTRY \& SECURITY REVIEW: 1/2019 ISSN 1802-4300 .

[9] NAGY I: A fegyverzettechnikai mühelygépkocsik és korszerüsitésük módjai, http://epa.oszk.hu/02700/02735/00031/pdf/EPA02735_katonai_logisztika_1999_4_111127.pdf (letöltve: 2019.01.15.)

[10]KOZÁK A.: Az integrált katasztrófavédelem szervezeti fejlődése 1990-töl. HADMÉRNÖK ISSN: 1788-1919, VIII. Évfolyam 2. szám - 2013. június, pp. 210-226. http://hadmernok.hu/132_19_kozaka.pdf (letöltve: 2019.03.15.)

[11]Magyar Védelmiipari Szövetség honlap, fotógaléria, http://vedelmiipar.hu/?lang=hun\&mnuGrp=mnuGalery|mnuGalPhotos\&module=galery\&si te=selected (letöltve: 2019.04.02.)

[12]HEIZLER Gy.: Müszaki fejlesztés - új jármüvek az önkénteseknek, Védelem, Katasztrófavédelmi szemle ISSN:2064-1559, 2015/6 p55.

[13]BARHÁCS A.: Mahindra cserefelépítményes gyorsbeavatkozó szer, Védelem, Katasztrófavédelmi szemle ISSN:2064-1559, 2015/6 pp. 56-58.

[14]HOFFMAN I., KÁTAI-URBÁN I, VASS GY.: Vegyi- és sugárfelderités katasztrófavédelmi technikai eszközrendszerének vizsgálata I. rész, Telepített rendszerek, HADMÉRNÖK, ISSN: 1788-1919, XI. Évfolyam 1. szám -2016. március, pp. 89-97. (2016), http://www.hadmernok.hu/161_09_hoffmanni_kui_vgy.pdf (letöltve: 2019.03.31) 